\title{
Antibacterial and cytotoxicity activities and phytochemical analysis of three ornamental plants grown in Mexico
}

\section{PATRICIA RÍOS-CHÁVEZ ${ }^{1}$, JORDY PEREZ-GONZALEZ ${ }^{1}$, RAFAEL SALGADO- GARCIGLIA ${ }^{2}$, ENRIQUE RAMÍREZ-CHÁVEZ ${ }^{3}$, JORGE MOLINA-TORRES ${ }^{3}$, MIGUEL MARTINEZ-TRUJILLO ${ }^{1}$ and YAZMIN CARREON-ABUD ${ }^{1}$}

\author{
${ }^{1}$ Facultad de Biología, Universidad Michoacana de San Nicolás de Hidalgo, Cd. \\ Universitaria, C.P 58030, Morelia, Michoacán, México \\ ${ }^{2}$ Instituto Químico Biológico, Universidad Michoacana de San Nicolás de Hidalgo, \\ Cd. Universitaria, C.P 58030, Morelia, Michoacán, México \\ ${ }^{3}$ Departamento de Biotecnología y Bioquímica Cinvestav-Irapuato, Km 9.6, \\ Libramiento Norte, C.P 36821, Irapuato, Guanajuato, México
}

Manuscript received on May 11, 2018; accepted for publication on September 9, 2018

\begin{abstract}
How to cite: RÍOS-CHÁVES P, PEREZ-GONZALEZ J, SALGADO-GARCIGLIA R, CHÁVEZ ER, TORRES JM, MARTINEZ-TRUJILLO M AND CARREON-ABUD Y. 2019. Antibacterial and cytotoxicity activities and phytochemical analysis of three ornamental plants grown in Mexico. An Acad Bras Cienc 91: e20180468. DOI 10.1590/0001-3765201920180468.

Abstract: This study evaluates the antibacterial, cytotoxic activities, and phytochemical composition, of Callistemon citrinus, Hibiscus rosa-sinensis and Plumbago auriculata leaves and flowers, three ornamental plants in Mexico. However, in other countries offers a range of other uses. Ethanol extracts of C. citrinus leaf and flower presented stronger antibacterial activity than the extracts obtained from the other two plants. C. citrinus leaf showed low cytotoxicity $\left(\mathrm{LC}_{50}<600 \mu \mathrm{g} / \mathrm{mL}\right)$ on the brine shrimp test, whereas the ethanol extracts of $H$. rosa-sinensis and P. auriculata leaves showed no cytotoxic activity. Flower extracts obtained from the three plants did no exhibit cytotoxicity. GC-MS analysis revealed that the ethanol extract of $P$. auriculata leaf contained lupeol triterpene and lupeol acetate, neither of them have been previously reported in this genus. Gamma sitosterol was present in the leaf and flower extracts of $P$. auriculata. Higher contents of linoleic and linolenic acids were found in extracts of $H$. rosa-sinensis leaves and flowers. The ability of the ethanol extracts of $C$. citrinus leaves and flowers to inhibit the growth of Gram-positive and Gram-negative bacteria indicates a potentially broad antimicrobial spectrum. Moreover, the absence of cytotoxicity suggests the potential use of this plant to treat microbial infections.
\end{abstract}

Key words: Antibacterial, Artemia salina, Callistemon citrinus, cytotoxic, lupeol.

\section{INTRODUCTION}

The genus Callistemon (commonly known as bottlebrush) belongs to the family Myrtaceae. Native of Australia and spread all over the world.

Correspondence to: Patricia Ríos-Chávez

E-mail: prchavez17@gmail.com

ORCid: https://orcid.org/0000-0003-4285-8307
Callistemon species have various applications. In several countries, C. citrinus is used for forestry, essential oil production and weed control, whereas in Mexico it is used as an ornamental plant. Additionally, the presence of biological properties in Callistemon species have been reported. For instance, $C$. viminalis exhibits anti-inflammatory and antifungal activities, while $C$. rigidus and $C$. 
citrinus show antibacterial and antioxidant activities (Goyal et al. 2012). Previously, we reported the presence of 74 and 64 terpenic compounds in leaves and flowers, respectively, of C. citrinus from Mexico (Petronilho et al. 2013).

The genus Plumbago (Plumbaginaceae) is distributed in tropical and subtropical regions. $P$. auriculata has potential therapeutic activities, including antiatherogenic, cardiotonic, hepatoprotective, neuroprotective and central nervous system stimulant properties (Tharmaraj and Antonysamy 2015). Paiva et al. (2005) reported plumbagin (2-methyl-5-hydroxy-1,4naphthoquinone), epi-isoshinanolone, palmitic acid and sitosterol in the roots of $P$. auriculata. Ariyanathan et al. (2011) reported capensisone for the first time in the roots of $P$. capensis.

The genus Hibiscus (Malvaceae) is widely grown in tropical regions. In Mexico, only two species are well represented: Hibiscus sabdariffa, whose flower infusion is used to prepare beverages, and Hibiscus rosa-sinensis used only as an ornamental plant. In other countries, $H$. rosa-sinensis is used to treat bronchial catarrh, menorrhagia, hair loss and infertility. Additionally, antimicrobial, hypoglycemic, anticancer and antioxidant activities have been reported for this plant (Kumar et al. 2012). A phytochemical investigation reported the presence of alkaloids, flavonoids, phenols, tannins and terpenoids in leaf, stem and root extracts of $H$. rosa-sinensis (Divya et al. 2013). Ethanol extract of flower showed hexadecanoic acid, adipic acid and squalene as the major components (Bhaskar et al. 2011).

On the other hand, the indiscriminate usage of antibiotics has created the problem of antibiotic resistance; consequently, the search for new antimicrobial agents is a global concern. There is a particular revival of interest in herbal medicine assuming that medicine obtained from natural sources presents fewer side effects than synthetic pharmaceuticals. The aim of this study is to investigate and compare the antibacterial and cytotoxic activities and determine the chemical composition of the ethanol extracts of $C$. citrinus, $H$. rosa-sinensis and $P$. auriculata leaves and flowers, in an effort to add new uses of these plants in Mexico.

\section{MATERIALS AND METHODS}

\section{PLANT MATERIAL}

Leaves and flowers of Callistemon citrinus, Hibiscus rosa-sinensis and Plumbago auriculata were collected in Morelia, Michoacán, Mexico: latitude $19^{\circ} 40^{\prime} 45^{\prime \prime}$ and longitude $101^{\circ} 22^{\prime} 0$ '. Professor Patricia Silva, a plant taxonomist in the Department of Botany of the University of Michoacán, certified the taxonomic identity of the plant materials. Voucher specimens were deposited in the herbarium of the University of Michoacán (EBUM). The voucher numbers are as follows: C. citrinus is EBUM23538, H. rosa-sinensis is EBUM24073 and P. auriculata is EBUM24074.

\section{PREPARATION OF PLANT EXTRACTS}

Fresh leaves and flowers of C. citrinus, H. rosasinensis and $P$. auriculata were collected during the morning in April. Then, they were crushed using a blender and macerated in $90 \%$ ethanol or water $(1: 10 \mathrm{w} / \mathrm{v})$. The mixtures were left at room temperature and protected from light for a week. Afterwards, the ethanolic extracts were evaporated under reduced pressure at $45{ }^{\circ} \mathrm{C}$ using a rotary evaporator. Each concentrated crude extract, individually prepared, was weighed and stored at $4{ }^{\circ} \mathrm{C}$.

\section{MICROORGANISMS}

Bacterial strains were obtained from a local hospital in Morelia, Michoacán, Mexico. The microorganisms were Gram-negative: Escherichia coli, Salmonella typhimurium and Klebsiella pneumoniae; and Gram-positive: Staphylococcus 
aureus, Staphylococcus epidermidis and Staphylococcus saprophyticus.

\section{ANTIBACTERIAL ACTIVITY DETERMINATION}

The antibacterial activity of $C$. citrinus, H. rosasinensis and $P$. auriculata extracts was investigated by the agar diffusion method. Briefly, a suspension of the tested microorganism $10^{8}$ cells $/ \mathrm{ml}$ was spread on Petri plates with Luria agar. Dilutions of the stock solution containing 25, 50, 75 and $100 \mu \mathrm{g} / \mathrm{mL}$ were prepared in dimethyl sulfoxide (DMSO). Then, $5 \mu 1$ of each dilution was used to test the antimicrobial activity. The plates were incubated for 24 hours at $37^{\circ} \mathrm{C}$. The inhibition zone diameter was measured using a ruler and expressed in millimeters. The antibiotic cefotaxime $(30 \mu \mathrm{g} /$ $\mathrm{mL}$ ) was used as a positive control and the solvent used for dissolving the extracts was a mixture $90 \%$ ethanol/water in DMSO served as negative control. Six replicates for each concentration and controls were done.

\section{BRINE SHRIMP LETHALITY ASSAY}

An in vitro lethality assay of brine shrimp nauplii (Artemia salina) was used to detect cell toxicity. Brine shrimp eggs were placed in artificial seawater $(3.8 \% \mathrm{w} / \mathrm{v}$ sea salt in distilled water) and incubated at $24-28{ }^{\circ} \mathrm{C}$ in front of a lamp. Eggs were hatched within 24-h period providing a large number of larvae (nauplii). Ten nauplii $(97 \mu \mathrm{l})$ and $3 \mu \mathrm{l}$ of the extracts dissolved in DMSO $(1-1000 \mu \mathrm{g} / \mathrm{mL})$ were placed in each well of an ELISA plate. The plate was incubated at room temperature for 24 h. The number of dead (non-motile) nauplii was determined by visual examination under a stereo microscope. Then, all nauplii were scarified by the addition of $100 \mu \mathrm{l}$ of methanol to each well. After 20 minutes, the total number of nauplii/well were counted. Berberine sulfate was used as a positive control ( $\left.\mathrm{IC}_{50} 10 \mu \mathrm{g} / \mathrm{mL}\right)$, and DMSO was used as a negative control.

\section{GC-EI-MS ANALYSIS}

One microliter from the resultant extracts was injected into an Agilent Technologies 7890A gas chromatograph equipped with a $60 \mathrm{~m} \times 250 \mu \mathrm{m}$ (I.D.), $0.25 \mu \mathrm{m}$ film thickness DB1MS fused silica capillary column (J\&W Scientific Inc., Folsom, CA, USA) that was interfaced with an Agilent Technologies 5975C quadrupole spectrophotometer in MS detector with electron impact as the ionization source. A split injection ratio of 1:100 was used. The injection port temperature was set at $250{ }^{\circ} \mathrm{C}$. The oven temperature was programmed from $70{ }^{\circ} \mathrm{C}$ to $300{ }^{\circ} \mathrm{C}$ with an increase of $5{ }^{\circ} \mathrm{C} / \mathrm{min}$ and the transfer line was heated at $250{ }^{\circ} \mathrm{C}$. The ion source was set at $150{ }^{\circ} \mathrm{C}$ and the quadrupole at $250{ }^{\circ} \mathrm{C}$. Helium was used as carrier gas with a flow of $1.0 \mathrm{ml} / \mathrm{min}$ and a column head pressure of 12 psi. The mass spectrometer was operated in the electron impact mode (EI) at $70 \mathrm{eV}$, with a scan range of $50-500 \mathrm{~m} / \mathrm{z}$ in a $2^{-s}$ cycle, in a full scan acquisition mode. When available, identification of volatile compounds was achieved by comparing the GC retention times and mass spectra with those of the standard compounds. In addition, the mass spectra of the samples were compared with the Wiley (G1035B; Rev D.02.00; Agilent Technologies, Santa Clara, CA, USA) and NIST Mass Spectral Search Program; version 2.0f (Nist Data Center, Gaithersburg, MD, USA) libraries reference spectral bank. All measurements were made with at least three replicates, each of them representing the analysis of one different aliquot of the extract. The GC peak area data obtained were used to estimate the relative content of each component. The samples of $H$. rosa-sinensis were pre-derivatized using trimethylsilylation.

\section{RESULTS AND DISCUSSION}

\section{ANTIBACTERIAL ACTIVITY}

Tables I and II display the antibacterial activity of the ethanol extracts of C. citrinus, H. rosasinensis and $P$. auriculata leaves and flowers. $C$. 
TABLE I

Antibacterial activity of ethanol extracts of Callistemon citrinus, Plumbago auriculata and Hibiscus rosa-sinensis leaves.

\begin{tabular}{|c|c|c|c|c|}
\hline Bacterial strains & $\begin{array}{l}\text { C. citrinus } \\
25 \mu \mathrm{g} / \mathrm{mL}\end{array}$ & $\begin{array}{l}\text { P. auriculata } \\
100 \mu \mathrm{g} / \mathrm{mL}\end{array}$ & $\begin{array}{c}\text { H. rosa-sinensis } \\
100 \mu \mathrm{g} / \mathrm{mL}\end{array}$ & $\begin{array}{l}\text { Cefotaxime } \\
30 \mu \mathrm{g} / \mathrm{mL}\end{array}$ \\
\hline Escherichia coli & $13.10 \pm 0.37$ & $8.00 \pm 1.00$ & $6.30 \pm 1.15$ & $16.00 \pm 0.22$ \\
\hline Salmonella typhimurium & $14.10 \pm 0.78$ & $7.30 \pm 0.57$ & $6.30 \pm 0.15$ & $17.00 \pm 0.49$ \\
\hline Klebsiella pneumoniae & $13.20 \pm 0.98$ & $10.60 \pm 2.51$ & $10.33 \pm 0.57$ & $22.00 \pm 0.94$ \\
\hline Staphylococcus aureus & $14.10 \pm 0.32$ & $12.00 \pm 1.73$ & $6.60 \pm 0.87$ & $20.00 \pm 0.26$ \\
\hline Staphylococcus epidermidis & $15.10 \pm 0.67$ & $7.33 \pm 0.57$ & $6.60 \pm 0.59$ & $22.00 \pm 0.84$ \\
\hline Staphylococcus saprophyticus & $16.00 \pm 1.00$ & $11.00 \pm 1.00$ & 0.00 & $21.00 \pm 0.59$ \\
\hline
\end{tabular}

Inhibition zone $(\mathrm{mm})$; Values are given as mean $\pm \mathrm{SD}(\mathrm{n}=6)$. In the negative control, no inhibition was observed.

TABLE II

Antibacterial activity of ethanol extracts of Callistemon citrinus, Plumbago auriculata and Hibiscus rosa-sinensis flowers.

\begin{tabular}{|c|c|c|c|c|}
\hline \multirow[t]{2}{*}{ Bacterial strains } & C. citrinus & P. auriculata & $\begin{array}{l}H . \text { rosa- } \\
\text { sinensis }\end{array}$ & Cefotaxime \\
\hline & $25 \mu \mathrm{g} / \mathrm{mL}$ & $100 \mu \mathrm{g} / \mathrm{mL}$ & $100 \mu \mathrm{g} / \mathrm{mL}$ & $30 \mu \mathrm{g} / \mathrm{mL}$ \\
\hline Escherichia coli & $14.20 \pm 0.83$ & $9.60 \pm 0.57$ & 0.00 & $16.00 \pm 0.22$ \\
\hline Salmonella typhimurium & $15.60 \pm 0.43$ & $9.60 \pm 0.57$ & 0.00 & $17.00 \pm 0.49$ \\
\hline Klebsiella pneumoniae & $18.00 \pm 0.52$ & $11.00 \pm 0.00$ & 0.00 & $22.00 \pm 0.94$ \\
\hline Staphylococcus aureus & $19.40 \pm 0.49$ & $17.60 \pm 0.57$ & 0.00 & $20.00 \pm 0.26$ \\
\hline Staphylococcus epidermidis & $18.00 \pm 1.30$ & $9.60 \pm 0.57$ & 0.00 & $22.00 \pm 0.84$ \\
\hline Staphylococcus saprophyticus & $17.20 \pm 0.73$ & $11.30 \pm 2.30$ & 0.00 & $21.00 \pm 0.59$ \\
\hline
\end{tabular}

Inhibition zone $(\mathrm{mm})$; Values are given as mean $\pm \mathrm{SD}(\mathrm{n}=6)$. In the negative control, no inhibition was observed.

citrinus flowers exhibited the strongest activity (as determined by the zone of inhibition) against Gram-negative and Gram-positive bacteria: E. coli (14.20 \pm 0.83$),$ S. typhimurium (15.60 \pm 0.43$), K$. pneumoniae $(18.00 \pm 1.30 \mathrm{~mm})$, S. aureus $(19.40 \pm$ $0.49 \mathrm{~mm})$, S. saprophyticus $(17.20 \pm 0.73 \mathrm{~mm})$ and S. epidermidis $(18.00 \pm 1.30 \mathrm{~mm})$. Additionally, $C$. citrinus leaves exhibited good activity against $E$. coli $(13.10 \pm 0.37 \mathrm{~mm})$, Salmonella typhimurium $(14.10 \pm 0.78 \mathrm{~mm})$, K. pneumoniae (13.20 \pm 0.98 $\mathrm{mm})$, S. aureus $(14.10 \pm 0.32 \mathrm{~mm})$, S. saprophyticus $(16.00 \pm 1.00 \mathrm{~mm})$ and $S$. epidermidis $(15.10 \pm$ $0.67 \mathrm{~mm})$.

It is well known that Gram-positive bacteria are more susceptible to antibiotics than Gram-negative bacteria. This is attributed to structural variations observed in the cell envelope between Gram- positive and Gram-negative bacteria (Palombo and Semple 2001). Fayemi et al. (2017) reported that $2 \%$ of methanolic extract of $C$. citrinus leaves inhibits the growth of Listeria monocytogenes in beef burger. Cock (2012) reported that $C$. citrinus leaf methanol extract was unable to inhibit the growth of E. coli and K. pneumonia, while the $C$. citrinus flower had only an effect against $K$. pneumoniae. Conversely, we found that the ethanol extracts of $C$. citrinus leaves and flowers exhibited strong antibacterial activities against Gramnegative, similar to previously reported results for the crude extracts of $C$. linearis (Haque et al. 2013). Scur et al. (2016) reported that aqueous extract and essential oil of Psidium cattleianum another Myrtaceae showed weak activity against K. pneumoniae and S. epidermidis. However, in the 
present work, the aqueous extracts of $C$. citrinus did not show antibacterial activity. In addition, activity of solvents used as negative controls did not show inhibition.

As shown in Table I, P. auriculata leaf ethanol extract exhibited good activity against $S$. aureus $(12.00 \pm 1.73 \mathrm{~mm})$, S. saprophyticus $(11.00 \pm$ $1.00 \mathrm{~mm})$ and $K$. pneumoniae $(10.60 \pm 2.51 \mathrm{~mm})$, while inhibition against $E$. coli $(8.00 \pm 1.00 \mathrm{~mm})$, Salmonella typhimurium $(7.3 \pm 0.57 \mathrm{~mm})$ and $S$. epidermidis $(7.33 \pm 0.57 \mathrm{~mm})$ was moderate. These results are in agreement with the study of Tharmaraj and Antonysamy (2015). P. auriculata flower ethanol extract exhibited a stronger activity against S. aureus $(17.60 \pm 0.57 \mathrm{~mm})$, good activity against K. pneumoniae $(11.0 \pm 0 \mathrm{~mm})$ and $S$. saprophyticus $(11.30 \pm 2.30 \mathrm{~mm})$ and moderate activity against E. coli, S. typhimurium and S. epidermidis (Table II). Aqueous extracts of $P$. auriculata leaves and flowers did not show antimicrobial activity.

Ahmad et al. (1998) reported that aqueous and alcoholic extracts from the roots of $P$. zeylanica showed antibacterial activity against $S$. aureus, Pseudomonas aeruginosa, Bacillus subtilis, Proteus vulgaris and against the yeast $C$. albicans. However, Jeyachandran et al. (2009) reported that methanol and chloroform extracts of $P$. zeylanica L. exhibited good activity against $E$. coli, Salmonella typhy and $S$. aureus, moderate activity against K. pneumoniae, Serratia marcescens and Bacillus subtilis and low activity against Proteus vulgaris and Pseudomonas aeruginosas. Paiva et al. (2003) found that plumbagin isolated from the roots of $P$. scandens completely inhibited the growth of $S$. aureus and C. albicans; however, it was ineffective against $E$. coli and $S$. typhimurium. Dhale and Markandeya (2011) showed that $P$. zeylanica ethanol and chloroform leaf extracts have antibacterial activity against two Gram-negative bacteria: E. coli and Pseudomonas aeruginosa and two Gram-positive bacteria: S. aureus and Bacillus subtilis.
In this study, the ethanol extract of $H$. rosasinensis leaf exhibited a good activity against $K$. pneumoniae $(10.33 \pm 0.57)$ and moderate activity against $E$. coli $(6.30 \pm 1.15), S$. typhimurium (6.30 $\pm 0.15), S$. aureus $(6.60 \pm 0.87)$ and $S$. epidermidis $(6.60 \pm 0.54)$. Nonetheless, it was unable to inhibit the growth of $S$. saprophyticus (Table I). Aqueous extracts of $H$. rosa-sinensis leaf and flower failed to inhibit bacterial growth. We found that the ethanol extract of $H$. rosa-sinensis red flower was unable to inhibit the growth of the bacteria tested (Table II). Meanwhile Mak et al. (2013) showed that aqueous and ethanol extracts of fresh $H$. rosasinensis flowers selectively inhibited the growth of S. typhimurium and S. aureus, respectively. Ruban and Gajalakshmi (2012) showed that methanol extracts of dried flowers presented a maximum zone of inhibition against $B$. subtillis and E. coli. The authors did not mention the flower color. However, Patel et al. (2012) studied the antimicrobial activity of five cultivars of H. rosa-sinensis, and they found differences in their effectiveness against $S$. aureus, $B$. subtillis, and $S$. epidermidis depending on the color of the flower red, yellow, orange, pink and white.

Based on the diameters of the inhibition zone observed for all microorganisms, C. citrinus leaves and flowers have stronger and broader spectrums of antimicrobial activities than those of $P$. auriculata and $H$. rosa-sinensis. Previously, we reported high levels of terpenoids in C. citrinus; thus, the antimicrobial activity may be attributed to these compounds (Petronilho et al. 2013). The ethanol extracts of $P$. auriculata and $H$. rosa-sinensis leaves and flowers not presented a minimal inhibitory concentration (MIC) as they were active only at $100 \mu \mathrm{g} / \mathrm{mL}$. On the other hand, the ethanol extracts of $C$. citrinus leaves and flowers exhibited a MIC value of $25 \mu \mathrm{g} / \mathrm{mL}$ against all bacterial strains. This value is lower than the cefotaxime used as positive control, suggesting that the major compounds 
present in the extracts possess antibacterial activity that could be used therapeutically.

\section{CYTOTOXIC ACTIVITY}

The cytotoxic activity of both flowers and leaves extracts of C. citrinus, $P$. auriculata and $H$. rosa-sinensis were tested in vitro against brine shrimp nauplii using the procedure described by Meyer et al. (1982). It was important to test the cytotoxic activity of the plants studied, in order to elucidate completely the biological response to their extracts. The brine shrimp lethality assay is a rapid, inexpensive and simple bioassay for testing plant extracts bioactivity, which, in most cases, is correlated with cytotoxic and anti-tumor properties (Maridass 2008). Ali et al. (2011) reported cytotoxic activity of the methanol $C$. citrinus crude fruit extract with an $\mathrm{LC}_{50}$ of $65 \mu \mathrm{g} / \mathrm{mL}$.

In the results presented in Table III, $C$. citrinus flower extract did not show cytotoxic activity against brine shrimp nauplii, while the leaf extract showed a $\mathrm{LC}_{50}<600 \mu \mathrm{g} / \mathrm{mL}$. A plot of the relationship between shrimp nauplii killed and the concentrations of the extract allows us to determinate the $\mathrm{LC}_{50}$ value of the plant extract. A regression analysis then determines the bestfit line. In a toxicity evaluation of plant extracts using a brine shrimp lethality bioassay, Ayo et al. (2007) reported that $\mathrm{LC}_{50}$ values smaller than 1000 $\mu \mathrm{g} / \mathrm{mL}$ are considered bioactive. Therefore, $C$. citrinus flower and leaf extracts can be considered non-toxic, justifying the continuation of biological experimentation to evaluate their pharmacological effects. Similarly, the extracts of $P$. auriculata and H. rosa-sinensis leaves and flowers did not show significant values in the mortality percentage among the different concentrations (Table III). In addition, DMSO used as negative control did not show cytotoxic activity.

\section{CHEMICAL COMPOSITION}

Jazet et al. (2009), Oyedeji et al. (2009) and Silva et al. (2010) studied the chemical composition of $C$. citrinus from Cameroon, South Africa and Brazil by GC-MS. They reported variances in the yields and chemical constituents that they attributed to a difference in geographical and environmental factors. Nevertheless, all studies showed the presence of three monoterpenenes: 1,8-cineole, $\alpha$-pinene and 4-terpineol.

In a previous study, our group found that the major components of the leaf extract of $C$. citrinus from 4-year-old plants were 1,8-cineole (14.73\%), limonene (9.12\%), $\alpha$-terpineol $(5.41 \%)$ and

TABLE III

Mortality rate \% of brine shrimp nauplii with different concentrations of Callistemon citrinus, Plumbago auriculata and Hibiscus rosa-sinensis extracts.

\begin{tabular}{ccccccc}
\hline & \multicolumn{2}{c}{ C. citrinus } & \multicolumn{2}{c}{ P. auriculata } & \multicolumn{2}{c}{ H. rosa-sinensis } \\
Conc $\boldsymbol{\mu g} / \mathbf{m L}$ & Leaf & Flower & Leaf & Flower & Leaf & Flower \\
\hline 1000 & 82 & 0 & 23 & 22 & 12 & 5 \\
900 & 79 & 0 & 15 & 17 & 11 & 5 \\
800 & 76 & 0 & 13 & 11 & 11 & 4 \\
700 & 70 & 0 & 8 & 5 & 13 & 4 \\
600 & 56 & 0 & 5 & 12 & & 2 \\
500 & 49 & 0 & 3 & 10 & 7 & 2 \\
100 & 3 & 0 & 3 & 10 & 5 & 2 \\
10 & 0 & 0 & 2 & 7 & 5 & 0 \\
1
\end{tabular}

Berberine sulfate was used as a positive control $\left(\mathrm{IC}_{50} 10 \mu \mathrm{g} / \mathrm{mL}\right)$. 
spathulenol(4.51\%), whereas the major components in flower extracts of plants of the same age were p-cymene (9.45\%), limonene (9.23\%), 1,8-cineole (6.98\%) and spathulenol (6.97\%) (Petronilho et al. 2013). Concentrations of terpenoids are generally higher in reproductive structures and the foliage during and immediately after flowering.

The antibacterial activities observed here could be attributed to the presence of some of the reported compounds that have been associated with this activity. 1,8-cineole, displays antimicrobial (Hendry et al. 2009) and anti-inflammatory activities (Ganjewala and Luthra 2010). Limonene has antibacterial effects (Soković et al. 2010) and protective activity against many types of cancer (Gershenzon et al. 2000).

In this study, the ethanolic extracts of $C$. citrinus of leaf and flower exhibited strong antibacterial activity, as reported by Larayetan et al. (2017) for essential oil of $C$. citrinus. This antimicrobial activity could be associated with the high percent of 1,8-cineole, limonene and spathulenol that are the major constituents of the leaf and flower. Antibacterial activities of these compounds have been reported by other studies (Bevilacqua et al. 2010, Boligon et al. 2014); other components such 4-terpineol, linalool and $\alpha$-terpinolene contributed to antibacterial activity as well (Park et al. 2012). It is also possible that some components will be involved in some type of synergism as Simsek and Duman (2017) for 1,8-cineole with chlorhexidine gluconate against $S$. aureus, E. coli and $K$. pneumoniae. Leaf and flower extracts of 20-yearold C. citrinus plants present high levels of these compounds (Petronilho et al. 2013).

The high levels of 1,8-cineole, limonene, $\alpha$-terpinolene and spathulenol, in C. citrinus suggest that it may constitute an alternative commercial source of these compounds. Finally, evidence of antimicrobial activity against a wide range of Gram-positive and Gram-negative bacteria from the ethanol extracts obtained from the leaves and flowers of $C$. citrinus, along with the lack of cytotoxic effects against $A$. salina, shows the potential of this plant for medicinal uses in Mexico.

This is the first study of a phytochemical screening using GC-MS analysis in Plumbago auriculata. This analysis identified eight compounds in the leaf and flower extracts (Figure 1, Table IV). The major constituents found in the leaves were phytol (31.60\%), lupeol acetate (20.50\%), lupeol (7.35\%), ethyl $\alpha$-D-glucopyranoside (4.55\%), gamma-sitosterol (3.17\%) and 2,3-dihydro-3,5dihydroxy-6-methyl-4H-pyran-4-one or DDMP $(1.50 \%)$. The present study revealed the presence of lupeol triterpene and lupeol acetate, both of which have not been previously reported in this genus. Additionally, the steroid gamma sitosterol has only been reported in the roots of Plumbago species (Paiva et al. 2005). Na et al. (2009) reported that lupeol and lupenone inhibit protein tyrosine phostase $1 \mathrm{~B}$, which appears to be an attractive target of new drugs in development for type 2 diabetes and obesity. Gallo and Sarachine (2009) also reported anticancer, antiprotozoal, chemopreventive and anti-inflammatory properties.

Concerning $P$. auriculata flowers, their major constituents were gamma-sitosterol (23.30\%), phytol $(21.93 \%)$, caffeine $(4.66 \%)$, DDMP $(2.47 \%)$, theobromine $(1.97 \%)$ and ethyl $\alpha$-Dglucopyranoside $(1.14 \%)$. Gamma-sitosterol has demonstrated strong cytotoxity on breast and lung cancer cell (Sundarraj et al. 2012). Phytol is a diterpenes that presents antimicrobial and anticancer activities (Saeb and Gholamrezaee 2012). In our study, we found that phytol is the major compound in the leaves and flowers of P. auriculata and both extracts have the highest antibacterial activity against $S$. aureus. Santos et al. (2013) reported that phytol inhibit the growth of $S$. aureus, and presents antinociceptive and antioxidant activities. Therefore, this compound is probably related to its antibacterial activity. The presence of caffeine 


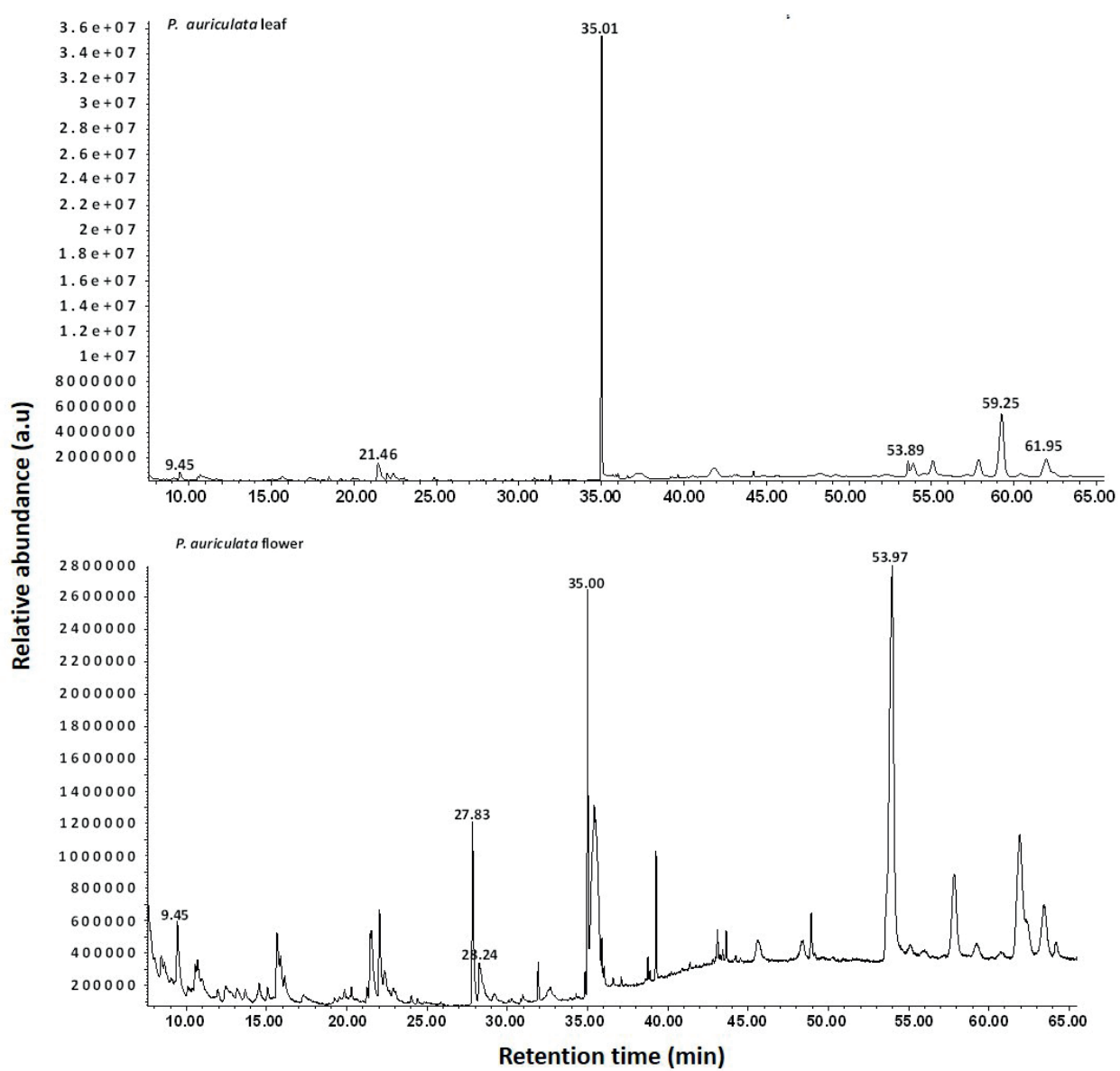

Figure 1 - Gas chromatogram of Plumbago auriculata, peak labels correspond to major compound identification given in Table IV.

and theobromine in the flower might be useful for making alternative tea beverages.

Pyo et al. (2004) showed that 5-hydroxymethyl2-furancarboxaldehyde has anti-platelet activity. Several researchers found important biological activities of DDMP such anti-alpha-glucosidase activity in patients with diabetes mellitus, (Quan et al. 2003), reactive oxygen scavenging activity (Hwang et al. 2013) and anti-tumor activity (Ban et al. 2007).

GC-MS analysis of the ethanol extracts of H. rosa-sinensis leaves and flowers led to the identification of 16 compounds in the leaves and seven in the flowers. Figure 2 and Table $\mathrm{V}$ display the identified constituents with their respective percentages and retention time. The major constituents of the leaves were fructose (18.60\%), 9,12-octadecadienoic acid (10.36\%), $9,12,15$-octadecatrienoic acid (7.67\%) and glycerol $(6.18 \%)$, while the main constituents of the flowers were 9,12-octadecadienoic acid (14.65\%), 9,12,15-octadecatrienoic acid (11.67\%), fructose (10.04\%) and $n$-hexadecanoic acid (4.13\%). There are some studies on the fatty-acid composition of the seeds of several Hibiscus species (Mohamed et al. 2007).

There are numerous varieties, cultivars and hybrids of Hibiscus rosa-sinensis. Their flowers colors can range from white, yellow, orange, scarlet and shades of pink, and can contain both single and double sets of petals. Patel et al. (2012) showed that the levels of some compounds were different in the 
TABLE IV

Screening of the compounds identified in ethanol extracts of Plumbago auriculata L. leaves and flowers, using GC-MS.

\begin{tabular}{|c|c|c|c|c|}
\hline $\operatorname{tr}(\min )^{a}$ & $m / z$ fragmentation pattern & Compounds & $\begin{array}{l}\text { Percentage } \\
\text { in leaf }(\%)^{b^{*}}\end{array}$ & $\begin{array}{l}\text { Percentage in } \\
\text { flower }(\%)^{b^{*}}\end{array}$ \\
\hline 9.44 & $\begin{array}{c}144(37), 101(31), 73(14), 72(20), 55(25), 45 \\
\quad(25), 44(76), 43(100), 42(9), 41(5)\end{array}$ & $\begin{array}{l}\text { 2,3-Dihydro-3,5-dihydroxy- } \\
\text { 6-methyl-4H-pyran4-one }\end{array}$ & $1.50(8)$ & $2.47(4)$ \\
\hline 10.56 & $\begin{array}{l}126(78), 125(15), 109(14), 97(100), 69(33), \\
53(15), 51(12), 41(73), 39(36), 29(17)\end{array}$ & $\begin{array}{l}\text { 5-Hydroxymethyl-2- } \\
\text { furancarboxaldehyde }\end{array}$ & $0.29(4)$ & $0.54(5)$ \\
\hline 21.46 & $\begin{array}{c}75(21), 74(16), 73(34), 71(15), 60(100), 57 \\
(25), 47(25), 45(21), 43(40), 42(43)\end{array}$ & Ethyl $\alpha$-D-glucopyranoside & $4.55(9)$ & $1.14(8)$ \\
\hline 27.83 & $\begin{array}{c}195(10), 194(100), 193(14), 110(9), 109(74) \\
82(30), 81(8), 67(46), 55(43), 42(15)\end{array}$ & Caffeine & n.d & $4.66(2)$ \\
\hline 28.24 & $\begin{array}{l}181(10), 180(100), 137(13), 109(24), 82(23) \\
\quad 67(35), 55(29), 40(7), 28(10), 15(10)\end{array}$ & Theobromine & n.d & $1.97(5)$ \\
\hline 31.91 & $\begin{array}{l}101(70), 88(100), 73(23), 71(19), 70(15), 69 \\
\quad(23), 57(40), 55(50), 43(57), 41(48)\end{array}$ & $n$-Hexadecanoic acid & $0.40(2)$ & $0.67(2)$ \\
\hline 35.01 & $\begin{array}{l}123(18), 81(22), 71(100), 69(24), 68(20), 57 \\
\quad(33), 56(17), 55(26), 43(38), 41(26)\end{array}$ & Phytol & $31.60(5)$ & $21.93(6)$ \\
\hline 53.97 & $\begin{array}{c}414(35), 145(32), 107(44), 95(45), 81(48), 69 \\
\quad(36), 57(56), 55(67), 43(100), 41(50)\end{array}$ & $\gamma$-Sitosterol & $3.17(3)$ & $23.32(6)$ \\
\hline 59.25 & $\begin{array}{l}424(63), 205(100), 123(43), 121(47), 109(76), \\
\quad 108(39), 107(46), 95(67), 93(40), 81(49)\end{array}$ & Lupenone & $20.50(9)$ & n.d \\
\hline 62.95 & $\begin{array}{l}109(61), 95(72), 93(68), 81(76), 69(73), 68 \\
\quad(98), 67(78), 55(87), 43(100), 41(67)\end{array}$ & Lupeol & $7.35(3)$ & n.d \\
\hline
\end{tabular}

${ }^{a} \operatorname{tr}(\min )$ : retention times (in minutes) of each compound identified.

${ }^{\mathrm{b}}$ Percentage of each component is calculate as peak area of analyte divide by total peak area n.d. (not detected).

*Relative Standard Deviation (RSD, \% in parentheses).

leaves and stems from five cultivars with different flower colors. Prasad (2014) showed the presence of different phytochemical constituents in nine different varieties of Hibiscus species. These huge varieties in H. rosa-sinensis make it difficult to compare with the compounds previously reported in these plants.

\section{CONCLUSION}

This study found strong antibacterial activities against to Gram-negative and Gram-positive bacteria and no cytotoxity activities of $C$. citrinus extracts that supports the potential use of phytomedicine in microbial infections. The antibacterial property may be attributed to terpenes present in the ethanolic extracts of leaves and flower.
Further studies are required to isolate and identify active compounds. The phytochemical screening using GC-MS analysis in Plumbago auriculata revealed for the first time high level of lupeol, lupeol acetate and DDMP, compounds reported to have pharmaceutical properties. Moreover, $H$. rosa-sinensis showed potential application as a nutritional source of essential fatty acids. Finally, the extracts of the three plants tested seemed to be innocuous on short-term use.

\section{ACKNOWLEDGMENTS}

The authors would like to thank the Scientific Research Coordination for the financial support of this work. 
TABLE V

Screening of the compounds identified in ethanol extracts of Hibiscus rosa-sinensis leaves and flowers using GC-MS.

\begin{tabular}{|c|c|c|c|c|}
\hline $\operatorname{tr}^{\mathrm{a}}$ & $m / z$ fragmentation pattern & Compounds & Leaf $(\%)^{b^{*}}$ & Flower $(\%)^{\mathbf{b}}$ \\
\hline 7.40 & $\begin{array}{c}147(20), 144(16), 133(15), 132(92), 116(100) \\
103(19), 75(30), 73(92), 57(17), 45(15)\end{array}$ & Serine & $0.87(4)$ & n.d \\
\hline 7.76 & $\begin{array}{l}218(17), 206(13), 205(63), 147(57), 133(16), \\
117(28), 103(30), 75(11), 73(100), 45(10)\end{array}$ & Glycerol & $6.18(5)$ & n.d \\
\hline 8.72 & $\begin{array}{c}247(10), 246(20), 245(100), 147(35), 143(12) \\
133(7), 83(8), 75(21), 73(45), 45(12)\end{array}$ & Fumaric acid & $0.89(7)$ & n.d \\
\hline 12.28 & $\begin{array}{c}258 \text { (7), } 230(8), 158(5), 157(15), 156(100), 147 \\
\text { (19), } 75(10), 74(7), 73(78), 45(13)\end{array}$ & Proline & $0.42(2)$ & n.d \\
\hline 20.06 & $\begin{array}{c}465(21), 375(38), 347(40), 363(43), 275(14) \\
274(32), 273(100), 147(69), 75(15), 73(90)\end{array}$ & Isocitric acid & $1.52(3)$ & n.d \\
\hline 20.35 & $\begin{array}{l}437(23), 219(12), 218(22), 217(100), 205(15), \\
204(25), 147(27), 103(11), 75(18), 73(94)\end{array}$ & Fructose & $18.60(5)$ & $10.04(8)$ \\
\hline 21.18 & $\begin{array}{l}319(13), 219(9), 218(21), 217(100), 205(7) \\
191(21), 147(20), 75(7), 74(7), 73(82)\end{array}$ & Galactose & $1.13(2)$ & $2.04(4)$ \\
\hline 23.46 & $\begin{array}{c}101(56), 89(14), 88(100), 73(16), 69(13), 57 \\
(22), 55(23), 43(36), 41(27), 29(23)\end{array}$ & n-Hexadecanoic acid & $1.31(3)$ & $4.13(7)$ \\
\hline 23.75 & $\begin{array}{l}321(13), 320(27), 319(94), 307(27), 217(37), \\
206(14), 205(72), 147(34), 103(31), 73(100)\end{array}$ & Glucitol & $0.18(7)$ & n.d \\
\hline 24.40 & $\begin{array}{l}218(7), 217(27), 206(8), 205(20), 204(100), \\
192(7), 191(39), 147(17), 129(6), 73(55)\end{array}$ & Talose & $2.64(3)$ & $2.04(2)$ \\
\hline 25.70 & $\begin{array}{c}339(28), 338(100), 323(43), 308(25), 293(13) \\
249(43), 219(15), 75(27), 73(86), 45(18)\end{array}$ & Cinnamic acid & $0.44(6)$ & n.d \\
\hline 25.91 & $\begin{array}{c}319(13), 318(30), 305(22), 217(26), 204(13) \\
191(18), 147(32), 129(7), 74(9), 73(100)\end{array}$ & Inositol & $2.98(7)$ & n.d \\
\hline 27.17 & $\begin{array}{l}96(48), 95(68), 82(57), 81(92), 69(45), 68 \\
\quad(61), 67(100), 55(77), 54(53), 41(71)\end{array}$ & 9,12-Octadecadienoic acid & $10.36(8)$ & $14.65(4)$ \\
\hline 27.28 & $\begin{array}{l}108(43), 95(52), 93(52), 91(31), 81(44), 80 \\
\quad(41), 79(100), 67(63), 55(46), 41(40)\end{array}$ & $9,12,15$-Octadecatrienoic acid & $7.67(5)$ & $11.67(7)$ \\
\hline 29.22 & $\begin{array}{c}341(90), 342(27), 145(42), 132(58), 129(38), \\
117(95), 75(78), 73(100), 55(26), 43(35)\end{array}$ & $n$-Octadecanoic acid & $2.56(3)$ & $1.97(6)$ \\
\hline
\end{tabular}




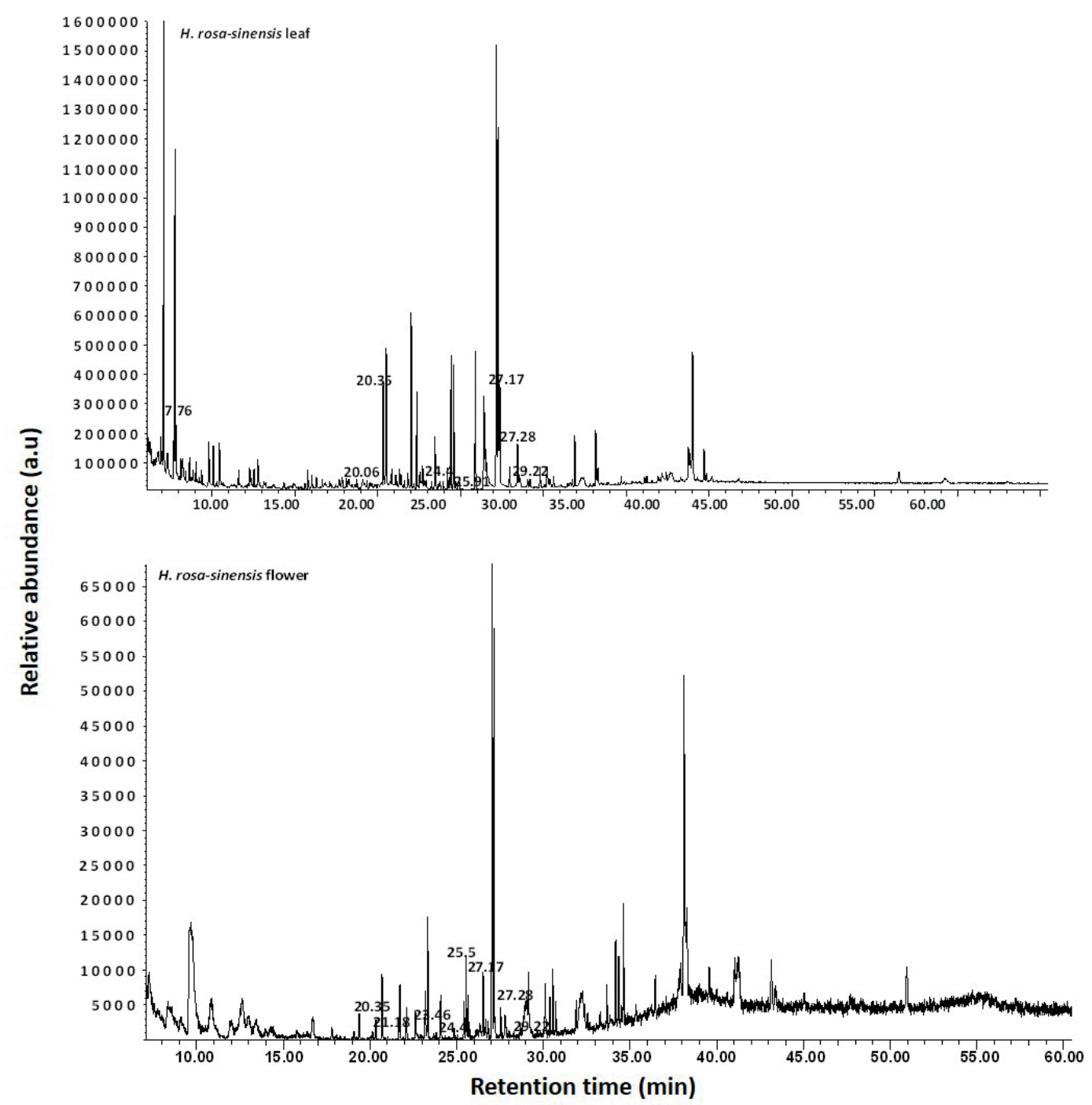

Figure 2 - Gas chromatogram of Hibiscus rosa-sinensis, peak labels correspond to major compound identification given in Table $\mathrm{V}$.

\section{AUTHOR CONTRIBUTIONS}

Dra. Patricia Ríos-Chávez was involved in the manuscript preparation, designed and supervised this research. Student Jordy Perez-Gonzalez performed the laboratory tests; Dr. Rafael SalgadoGarciglia supervised cytotoxity experimentation; MSc. Enrique Ramirez-Chavez and Dr. Jorge Molina-Torres supervised phytochemical analysis; Miguel Martinez-Trujillo and Dra. Yazmin CarreonAbud supervised antibacterial experimentation. All authors approved the manuscript.

\section{REFERENCES}

AHMAD I, MEHMOOD Z AND MOHAMMAD F. 1998. Screening of some Indian medicinal plants for their antimicrobial properties. J Ethnopharmacol 62: 183-193.

ALI N, AHMED G, SHAH SWA, SHAH I, GHIAS M AND KHAN I. 2011. Acute toxicity, brine shrimp cytotoxicity and relaxant activity of fruits of Callistemon citrinus Curtis. BMC Compl Alternat Med 1: 1-8.

ARIYANATHAN S, SARASWATHY A AND RAJAMANICKAM GV. 2011. Phytochemical investigation of Plumbago capensis Thumb. Int J of Pharm \& Life Sci 2: 670-673.

AYO RG, AUDU OT AND AMUPITAN JO. 2007. Physicochemical characterization and cytotoxicity studies of 
seed extracts of Khaya senegalensis (Desr.) A. Juss. Afr J Biotechnol 6: 894-896.

BAN JO, HWANG IG, KIM TM, HWANG BY, LEE US, JEONG HS, YOON YW, KIM DJ AND HONG JT. 2007. Anti-proliferate and pro-apoptotic effects of 2,3-dihydro3,5-dihydroxy-6-methyl-4H-pyranone through inactivation of NF-кB in human colon cancer cells. Arch Pharm Research 30: 1455-1463.

BEVILACQUA A, CORBO MR AND SINIGAGLIA M. 2010. In vitro evaluation of the antimicrobial activity of eugenol, limonene, and citrus extract against bacteria and yeasts, representative of the spoiling microflora of fruit juices. J Food Prot 73: 888-894

BHASKAR A, NITHYA V AND VIDHYA VG. 2011. Phytochemical screening and in vitro antioxidant activities of the ethanolic extract of Hibiscus rosa-sinensis L. Ann Biol Res 2: 653-661.

BOLIGON AA, PIAMA M, DE BRUM TF, FROEDER ALF, BELKE BV, SCHWANZ TG, MARIO DN, ALVES SH AND ATHAYDE ML. 2014. Scutia buxifolia Reissek essential oil: in vitro antioxidant and antimicrobial activities. An Acad Bras Cienc 86: 1463-1469

COCK IE. 2012. Antimicrobial activity of Callistemon citrinus and Callistemon salignus methanolic extracts. Phcog Commn 2: 50-57.

DHALE DA AND MARKANDEYA SK. 2011. Antimicrobial and phytochemical screening of Plumbago zeylanica Linn. (Plumbaginaceae) leaf. J Exp Sci 2: 4-6.

DIVYA MJ, SOWMIA C, DHANYA KP AND JOONA K. 2013. Screening of antioxidant, anticancer activity and phytochemicals in methanolic extract of Hibiscus rosasinensis leaf extract. Res J Pharmaceut Biol Chem Sci 4: 1308-1316.

FAYEMI PO, ÖZTÜRK I, ÖZCAN C, MUGURUMA M, YETIM H, SAKATA R AND AHHMED A. 2017. Antimicrobial activity of extract of Callistemon citrinus flowers and leaves against Listeria monocytogenes in beef burger. Food Measure 11: 924-929.

GALLO MBC AND SARACHINE MJ. 2009. Biological activities of lupeol. Int J Biomed Pharm Sci 3: 46-66.

GANJEWALA D AND LUTHRA R. 2010. Essential oil biosynthesis and regulation in the genus Cymbopogon. Nat Prod Commun 5: 163-172.

GERSHENZON J, MCCONKEY ME AND CROTEAU RB. 2000. Regulation of monoterpene accumulation in leaves of peppermint. Plant Physiol 122: 205-213.

GOYAL PK, JAIN R, JAIN S AND SHARMA A. 2012. A review on biological and phytochemical investigation of plant genus Callistemon. Asian Pac J Trop Biomed 2: S1906-S1909.

HAQUE A, SIDDIQI MMA, RAHMAN AFMM, CHOWDHURY AMS AND CHOUDHURY MH. 2013.
Antimicrobial and cytotoxic activities of the crude extracts of Callistemon linearis. Int J Biosci 3: 129-133.

HENDRY ER, WORTHINGTON T, CONWAY BR AND LAMBERT PA. 2009. Antimicrobial efficacy of eucalyptus oil and 1,8 cineole alone and in combination with chlorhexidine digluconate against microorganisms grown in planktonic and biofilm cultures. J Antimicrob Chemother 64: 1219-1225.

HWANG IG, KIM HY, WOO KS, LEE SH, LEE J AND JEONG HS. 2013. Isolation and identification of the antioxidant DDMP from heated pear (Pyrus pyrifolia Nakai). Pre Nutr Food Sci 18: 76-79.

JAZET PMD, TATSADJIEU LN, NDONGSON BD, KUATE J, AMVAM ZPH AND MENUT C. 2009. Correlation between chemical composition and antifungal properties of essential oils of Callistemon rigidus and Callistemon citrinus of Cameroon against Phaeoramularia angolensis. J Med Plant Res 3: 009-015.

JEYACHANDRAN R, MAHESH A, CINDRELLA L, SUDHAKAR S AND PAZHANICHAMY K. 2009. Antibacterial activity of Plumbagin and root extracts of Plumbago zeylanica L. Acta Biol Cracov Ser Bot 51: 1722.

KUMAR L, CHAKRABORTHY G, SINGH V AND MAZUMDER A. 2012. Hibiscus rosa-sinensis: A Review on Divine Herb. J Adv Pharm Healthc Res 2: 9-18.

LARAYETAN RT, OKOH OO, SAIMENKO A AND OKOH AI. 2017. Terpene constituents of the aerial parts, phenolic content, antibacterial potential, free radical scavenging and antioxidant activity of Callistemon citrinus (Curtis) Skeels (Myrtaceae) from eastern Cape province of South Africa. BMC Complement Altern Med 17: 292-301.

MAK YW, CHUAH LO, AHMAD R AND BHAT R. 2013. Antioxidant and antibacterial activities of hibiscus (Hibiscus rosa-sinesis L.) and Cassia (Senna bicapsularis L.) flower extracts. J King Saud Univ Sci 25: 275-282.

MARIDASS M. 2008. Evaluation of brine shrimp lethality of Cinnamomum species. Ethnobotanical leaflets 12: 772775.

MEYER BN, FERRIGNI NR, PUTNAM JE, JACOBSEN LB, NICHOLS DE AND MCLAUGHLIN JL. 1982. Brine Shrimp: A convenient general bioassay for active plant constituents. Planta Med 45: 31-34.

MOHAMED R, FERNANDEZ J, PINEDA M AND AGUILAR M. 2007. Roselle (Hibiscus sabdariffa) seed oil is a rich source of gamma-tocopherol. J Food Sci 72: S207-S211

NA M, KIM BY, OSADA H AND AHN JS. 2009. Inhibition of protein tyrosine phosphate $1 \mathrm{~B}$ by lupeol and lupenone isolated from Sorbus commixta. J Enzym Inhib Med Chem 24: 1056-1059.

OYEDEJI OO, LAWAL OA, SHODE FO AND OYEDEJI AO. 2009. Chemical composition and antibacterial activity of 
the essential oils of Callistemon citrinus and Callistemon viminalis from South Africa Molecules 14: 1990-1998.

PAIVA SR, FIGUEIREDO MR, ARAGAO TV AND KAPLAN MA. 2003. Antimicrobial activity in vitro of plumbagin isolated from Plumbago species. Mem Inst Oswaldo Cruz 98: 959-961.

PAIVA SR, FIGUEIREDO MR AND KAPLAN MA. 2005. Isolation of secondary metabolites from roots of Plumbago auriculata Lam. By countercurrent chromatography. Phytochem Anal 16: 278-281.

PALOMBO EA AND SEMPLE SJ. 2001. Antibacterial activity of traditional Australian medicinal plants. J Ethnopharmacol 77: 151-157.

PARK SN, LIM YK, FREIRE MO, CHO E, JIN D AND KOOK JK. 2012. Antimicrobial effect of linalool, and $\alpha$-terpineol against periodontopathic and cariogenic bacteria. Anaerobe 18: 369-372.

PATEL R, PATEL A, DESAI S AND NAGEE A. 2012. Study of secondary metabolites and antioxidant properties of leaves, stem and root among Hibiscus rosa-sinensis cultivars. Asian J Exp Biol Sci 3: 719-725.

PETRONILHO S, ROCHA SM, RAMIREZ-CHAVEZ E, MOLINA-TORRES J AND RIOS-CHAVEZ P. 2013. Assessment of the terpenic profile of Callistemon citrinus (Curtis) Skeels from Mexico. Ind Crops Prod 46: 369-379.

PRASAD MP. 2014. In vitro phytochemical analysis and antioxidant studies of Hibiscus species. Int J Pure App Biosci 2: 83-88.

PYO MK, JIN JL, KOO YK AND YUN-CHOI HS. 2004. Phenolic and furan type compounds isolated from gastrodia elata and their anti-platelet effects. Arch Pharm Res 27: 381-385.

QUAN J, YIN X, JIN M AND SHEN M. 2003. Study on the inhibition of alpha-glucosidase by soyasaponins. Zhong Yao Cai 26: 654-656.

RUBAN P AND GAJALAKSHMI K. 2012. In vitro antibacterial activity of Hibiscus rosa-sinensis flower extract against human pathogens. Asian Pac J Trop Biomed 2: 399-403.

SAEB K AND GHOLAMREZAEE S. 2012. Variation of essential oil composition of Melissa officinalis L. leaves during different stages of plant growth. Asian Pac J Trop Biomed 2: 547-549.

SANTOS CCMP, SALVADORI MS, MOTA VG, COSTA LM, DE ALMEIDA AAC, DE OLIVEIRA GAL, COSTA JP, DE SOUSA DP, DE FREITAS RM AND DE ALMEIDA RN. 2013. Antinociceptive and antioxidant activities of phytol in vivo and in vitro models. Neuroscience J 2013: 1-9.

SCUR MC, PINTO FGS, PANDINI JA, COSTA WF, LEITE CW AND TEMPONI LG. 2016. Antimicrobial and antioxidant activity of essential oil and different plant extracts of Psidium cattleianum Sabine. Braz J Biol 76: 101-108.

SILVA CJ, BARBOSA LCA, DEMUNER AJ, MONTANARI RM, PINHEIRO AL, DIAS I AND ANDRADE NJ. 2010. Chemical composition and antibacterial activities from the essential oils of Myrtaceae species planted in Brazil. Quim Nova 33: 104-108.

SIMSEK M AND DUMAN R. 2017. Investigation of effect of 1,8-cineole on antimicrobial activitu of chlorhexidine gluconate. Pharmacognosy Res 9(3): 234-237.

SOKOVIĆC M, GLAMOČLIJA J, MARIN PD, BRKIĆ D AND GRIENSVEN LJLD. 2010. Antibacterial effects of the essential oils of commonly consumed medicinal herbs using an in vitro model. Molecules 15: 7532-7546.

SUNDARRAJ S, THANGAM R, SREEVANI V, KAVERI K, GUNASEKARAN P, ACHIRAMAN S AND KANNAN S. 2012. $\gamma$-Sitosterol from Acacia nilotica $\mathrm{L}$. induces G2/M cell cycle arrest and apoptosis through c-Myc suppression in MCF-7 and A549 cells. J Etnopharmacol 141: 803-809.

THARMARAJ RJJM AND ANTONYSAMY JM. 2015. Screening of bactericidal activity of selected Plumbago species against bacterial pathogens. J Microbiol Exp 2(6): 00070 . 